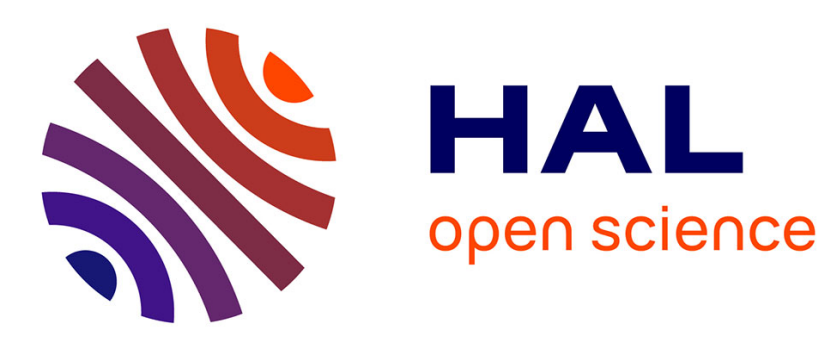

\title{
The influences of contamination during lamination on the properties of composite materials
}

\author{
G. Hall Beng, S. Mason
}

\section{To cite this version:}

G. Hall Beng, S. Mason. The influences of contamination during lamination on the properties of composite materials. Journal de Physique IV Proceedings, 1993, 03 (C7), pp.C7-1669-C7-1672. 10.1051/jp4:19937262 . jpa-00251902

\section{HAL Id: jpa-00251902 https://hal.science/jpa-00251902}

Submitted on 1 Jan 1993

HAL is a multi-disciplinary open access archive for the deposit and dissemination of scientific research documents, whether they are published or not. The documents may come from teaching and research institutions in France or abroad, or from public or private research centers.
L'archive ouverte pluridisciplinaire HAL, est destinée au dépôt et à la diffusion de documents scientifiques de niveau recherche, publiés ou non, émanant des établissements d'enseignement et de recherche français ou étrangers, des laboratoires publics ou privés. 


\title{
The influences of contamination during lamination on the properties of composite materials
}

\author{
G.M. HALL BENG and S.E. MASON
}

University of Portsmouth, School of Systems Engineering, Anglesea Road, Portsmouth, PO1 3DJ, U.K.

\begin{abstract}
The quality of a fibrous composite laminate can be largely attributed to the laminating process. It is therefore important to control parameters which will ultimately affect the desired quality of the laminate.

Although several composite manufacturing organisations have installed clean room facilities with the hope of controlling potential contaminants, which may be detrimental to the process, the unavoidable reductions in productivity, coupled with the initial capital and maintenance costs make it an expensive solution to an unquantified problem.
\end{abstract}

This study investigates the influences of contamination on structural fibre reinforced composites. Initial testing has involved contaminating Carbon/Epoxy (Fiberite 7714B) prepregs on a gross level. Contaminants have been selected on a tactile level in order to be as closely representative of situations likely to be encountered in the laminating process. The research has concentrated on airborne particulates, including fibres, condensation and humidity. Modes of contamination have been proposed for each, and suitable test methods selected to verify the modes. Test methods include the sort beam shear test (interlaminar shear strength), double cantilever beam test (interlaminar fracture data) and tensile tests. Such high levels of contamination enables the identification of those contaminants that are most detrimental to final laminate quality. Strategic reduction in the contamination levels of those identified will enable the clean room operating level to be sought.

\section{INTRODUCTION}

In order to assure processing quality, essential for repeatable laminate production, several composite manufacturing organisations have installed clean rooms for the laminating process of Fibre Reinforced Plastics (FRP). This approach allows control to be established over potential contaminants (primarily airborne particulates (BS 5295 ${ }^{1}$ ) as well as humidity and temperature) that were previously unknown process variables.

There are, however, several drawbacks. Productivity is reduced, comfortable working environments can be compromised and the initial capital and maintenance costs make it an expensive facility to solve a problem that may not exist. The research has therefore centred on identifying whether such a facility is necessary and beneficial in the composites field, and if so, to what level must such a facility operate in order to achieve these desired results.

\section{POTENTIAL CLEAN ROOM CONTAMINANTS}

Contaminants used in the research were chosen to analyse the effects of particulate contamination, contamination from humidity and from condensation. 


\section{THE EFFECTS OF CONTAMINATION ON FIBROUS COMPOSITE LAMINATE}

If contamination is detrimental to cured laminate property, then it must affect one or more of the criteria that define a good quality laminate 2 .
(1) Void content
(2) Proper level of laminate consolidation
(3) Proper degree of cure
(4) Proper fibre orientation.

\section{THE EFFECTS OF PARTICLES ON A FIBROUS COMPOSITE LAMINATE}

Suggested potential effects are outlined below, although the effects are not necessarily mutually exclusive.

1. Particles act as crack initiators

2. Particle stress adjacent fibres

3. Particles act as crack arrestors/promoters

4. Alteration in the laminate bond strength

5 Promotion of resin rich areas (contaminant geometry dependent)

6. Particles react with the composite

\section{THE EFFECTS OF MOISTURE ON EPOXY RESINS DURING THE CURE CYCLE}

Although the effects of moisture on the properties of composite materials are well researched, particularly on graphite epoxy laminates ${ }^{3}$, one area that has been greatly overlooked is that of moisture contamination on a catalysed resin system prior to cure.

From the previous work undertaken ${ }^{4-8}$ and observation, it is possible to propose a mode by which moisture will affect a b-staged epoxy during cure. This is not a single reaction or effect by the water, but rather a fairly complex combination of each. The proposed modes of action are highlighted below.

(i) The epoxy becomes plasticised by the water

(ii) The hardener is removed to a certain degree (depending on exact quantities) by steam distillation which will affect the stoichiometry between hardener and epoxy.

(iii) The temperature at which cross linking occurs is reduced.

(iv) The water chemically reacts with the epoxy.

\section{EXPERIMENTATION}

Modes for testing fibre reinforced plastic composites fall into one of two categories ie Fibre dominated tests or Matrix dominated tests. Test methods selected for the research depend on which proposed failure mode exists, whether the test method is repeatable and finally, whether the test data can be successfully analysed.

Appraisal of the current test methods has highlighted the following tests as valid

(i) Short beam shear test (SBS) (Established database, repeatable, establish matrix dominated data).

(ii) Double cantilever beam test (DCB) (Suitable for interlaminar fracture data and assessment of primary bond integrity)

(iii) Tensile test (suitable for fibre dominated tests).

\section{EXPERIMENTAL ASSUMPTIONS}

1. Voids present are well dispersed in the laminate. Any significant variations in property is due to contamination.

2. Laminate consolidation is the same for all samples - cure cycles are identical. Any variation in laminate bond strength is due to contamination. 
3. Degradation in property is nôt being sought, only changes in property compared to a control batch.

4. Control samples are selected so as to account for intraroll variations.

5. All specimens are from one roll to prevent interroll variations.

\section{MATERIALS}

The materials chosen for the work were representative of the majority of the current materials used in the laminating processes at Williams Grand Prix Engineering Ltd. Therefore, the composite systems adopted were those most utilised for structural components.

The material designations are shown below.

(i) HMF $371 / 7714 \mathrm{~B}-42 \%\left(125^{\circ} \mathrm{C}\right.$ curing woven c/epoxy composite)

(ii) HYE $33714 \mathrm{AD} / \mathrm{G}-42 \%\left(125^{\circ} \mathrm{C}\right.$ curing UD carbon/epoxy)

\section{EXPERIMENTAL PROCEDURE}

Test samples prepared as normal test process with the addition of the contaminant.

\section{SHORT BEAM SHEAR TEST}

Tests were carried out in accordance to ASTM D2344-84 (standard test method for apparent interlaminar shear strength of parallel fibre composites by short beam method) ${ }^{9}$.

UD samples were 12 ply giving a nominal thickness of $1.8 \mathrm{~mm}$.

Woven samples were 6 ply giving a nominal thickness of $1.8 \mathrm{~mm}$.

Span to thickness ratio was $4: 1 \pm 0.1$.

\section{RESULTS}

It is important to recognise that the short beam shear test is only one test in an ongoing test program. Contamination levels are high and as such provide only indications of the modes of contamination and not clean room acceptance levels. The results presented below are based on observation and numerical analysis.

\section{Statistical assumptions}

1. The number of control samples are significant to determine variations arising from contamination. 27 valid UD specimens along the experimental roll resulted in a standard deviation of approx $1 \mathrm{MPa}$. 28 valid woven specimens resulted in an sd of $2 \mathrm{MPa}$.

2. Limits of \pm 3 sd envelop all control samples - contaminated samples providing a significant number of results outside of this criterion are deemed to have an effect.

3. Control samples will normally distribute with a large enough batch size unless affected by low contamination levels.

\begin{tabular}{|l|l|l|l|l|l|l||}
\hline \hline Contaminant & UD/WOV & Mean ILSS (MPa) & $\%$ ILSS Change & DEV (MPa) & N $^{\circ}$ Samples & Significant Batch Variation \\
\hline Control & UD & 93.3 & $\pm 0 \%$ & 0.93 & 27 & No \\
& woven & 72.1 & $\pm 0 \%$ & 2.12 & 28 & Some Intraroll variation \\
\hline Hair & UD & 84.7 & $-9.2 \%$ & 4.09 & 20 & Yes (Mean) \\
& woven & 60.8 & $-15.7 \%$ & 7.75 & 18 & Yes (Mean \& Dev) \\
\hline \multirow{2}{*}{ Breather } & UD & 89.2 & $-4.4 \%$ & 0.80 & 19 & No \\
& woven & 64.8 & $-10.1 \%$ & 5.91 & 18 & Yes (Mean \& Dev) \\
\hline \multirow{2}{*}{ Sand } & UD & 81.9 & $-12.2 \%$ & 1.17 & 20 & No \\
& Woven & 63.6 & $-11.8 \%$ & 2.63 & 17 & Yes (Dev) \\
\hline \multirow{2}{*}{ Water } & UD & 66.5 & $-28.7 \%$ & 8.89 & 14 & No \\
\hline \multirow{2}{*}{ Hum } & Woven & 63.4 & $-12.1 \%$ & 1.27 & 20 & No \\
\hline
\end{tabular}




\section{SUMMARY}

1. The test for interlaminar shear strength is most useful, numerically, in determining bulk resin effects. Localised effects such as that with humidity can be difficult to identify.

2. Methods of contamination are difficult to control - this can lead to significant batch variations.

3. The effects of contaminants, particularly moisture, can vary according to the geometry of reinforcement.

4. The test concentrates on one mode of failure. Different effects may be sought in further tests.

5. All contaminants at these levels of concentration affect the laminate. In the case of humidity this is not apparent in values but is evident from graphical analysis.

6. Gross levels of contamination can in certain cases increase the probability of contamination occuring at critical sites. Reduction in strength is not entirely due to quantity.

\section{REFERENCES}

1. BS 5295: Parts 0-4, 'Environmental Cleanliness in Enclosed Spaces', 1989.

2. Engineered Materials Handbook, Vol 1, 'Composites' ASM INternational, 1987, p 730

3. Delasi, R and Whiteside, J B, 'Effect of Moisture on Epoxy Resins and Composites', Advances Composite Materials - Environmental Effects, 1978, ASTM STP 658, pp 2-20.

4. Stark, E B, Ibrahim, A M, Munns, T E, Seferis, J C, 'Moisture Effects During Cure of High Performance Epoxy Matrices', Journal of Applied Polymer Science, 1985, Volume 30, pp 1717-1731.

5. Darrow, C D, Ayers, J A, Brayden, T H, 'Experimental Investigation of the Reaction Between Epoxy Resins and Moisture at Cure Temperatures', 31st International SAMPE Symposium, April 7-10, 1986, pp 374-386.

6. Ashbee, K, 'Fundamental Principles of Fibre Reinforced Composites', Pennsylvania USA, Technomic Publishing Company Inc., 1989, p 35, ISBN 87762-597-2.

7. Billmeyer Jr., F W, 'Textbook of Polymer Science', 2nd Edition, ed USA: John Wiley and Sons Inc., 1971, p 478-480, ISBN 0471-07296-6.

8. Morrison and Boyd, 'Organic Chemistry', 2nd Edition ed. Boston USA, Allyn and Bacon Inc., 1971, p 875-892.

9. ASTM D2344-76, 'Apparent Horizontal Shear Strength of Reinforced Plastics by Short Beam Method', 1976.

\section{ACKNOWLEDGEMENTS}

This work has been funded by the University of Portsmouth and supply material and use of equipment have kindly been supported by Williams Grand Prix Engineering Ltd. 